\title{
The role of sample collection timing on interleukin-6 levels in early-onset neonatal sepsis
}

\author{
A influência do tempo de coleta \\ sobre os níveis de interleucina-6 na sepse neonatal precoce
}

Renato S. Procianoy ${ }^{1}$, Rita C. Silveira ${ }^{2}$

\begin{abstract}
Objective: To assess different perinatal findings and sample collection timing in newborns with early-onset sepsis comparing those with low IL-6 levels to the ones with high levels.

Methods: Eighty-five newborn infants, with clinical signs of sepsis and/or positive blood cultures, had plasma IL- 6 collected in the initial evaluation for early-onset sepsis in the first 96 hours of life. They were classified in two groups according to their plasma IL-6 levels: higher, and equal to or lower than IL-6 median value for the whole septic group

Results: Median IL-6 for the whole group was $89 \mathrm{pg} / \mathrm{ml}$. High and low level groups were formed by 42 and 43 newborns respectively. There were no differences between the two groups regarding gestational ages, birth weights, cesarean-section proportion, Apgar scores, number of neonates with maternal risk factors for infection, number of maternal intrapartum antibiotic therapy, and number of positive blood cultures. Median plasma IL- 6 in the high level group was $287 \mathrm{pg} / \mathrm{ml}$, and in the low level group $46 \mathrm{pg} / \mathrm{ml}(\mathrm{p}<0.001)$. Median sample timing was 17.5 hours of life for the high level group and 36 hours of life for the low level group $(p<0.001)$. There was a significant negative correlation coefficient between IL- 6 levels and sample collection timing.
\end{abstract}

Conclusion: Sample collection timing is an important factor for detection of high plasma IL-6 level in newborn infants with earlyonset sepsis.

J Pediatr (Rio J). 2004;80(5):407-10: Cytokines, neonatal sepsis, infection, interleukin-6.

\section{Resumo}

Objetivo: Avaliar os diferentes achados perinatais e o tempo da coleta da amostra em recém-nascidos com sepse neonatal precoce, comparando os recém-nascidos com nível baixo e alto de IL-6.

Métodos: Oitenta e cinco recém-nascidos com sinais clínicos de sepse e/ou hemoculturas positivas tiveram plasma coletado na avaliação inicial da sepse neonatal precoce nas primeiras 96 horas de vida. Foram divididos em: a) acima (grupo de nível elevado) e b) igual ou abaixo (grupo de nível baixo) da mediana da IL-6 do grupo total.

Resultados: A mediana da IL-6 para o grupo total foi de $89 \mathrm{pg} / \mathrm{ml}$. Os grupos de nível elevado e de nível baixo foram constituídos por 42 e 43 recém-nascidos, respectivamente. Não houve diferença significativa entre ambos os grupos quanto a idade gestacional, peso de nascimento, proporção de parto cesariano, escores de Apgar, número de recém-nascidos cujas mães tiveram fator de risco para infecção, número de mães que receberam antibiótico intraparto e número de hemoculturas positivas. A mediana da IL-6 plasmática do grupo de nível elevado foi $287 \mathrm{pg} / \mathrm{ml}$, e do grupo de nível baixo foi $46 \mathrm{pg} / \mathrm{ml}$ $(p<0,001)$. A mediana do tempo de coleta foi 17,5 horas de vida no grupo de nível elevado e 36 horas de vida no grupo de nível baixo ( $p$ $<0,001)$. Houve uma significante correlação negativa entre níveis de IL-6 e tempo de coleta da amostra.

Conclusão: $O$ tempo de coleta da amostra é um fator importante para a detecção de níveis elevados de IL-6 em recém-nascidos com sepse neonatal precoce.

J Pediatr (Rio J). 2004;80(5):407-10: Citoquinas, sepse neonatal, infecção, interleucina-6.

\section{Introduction}

The inflammatory response is mediated by cytokines that are used as neonatal infection markers, especially interleukin-6 (IL-6). IL-6 is an inducer of hepatic protein synthesis, promotes production and liberation of C-reactive protein, and can be detected early when there is bacterial bloodstream invasion. It acts as a signal for T-cell activation, promotes antibody secretion by $B$ cells and differentiation of cytotoxic T cells, and stimulates liberation of other cytokines, particularly TNF- $\alpha$ and II-1B. ${ }^{1-5}$
Suggested citation: Procianoy RS, Silveira RC. The role of sample collection timing on interleukin-6 levels in early-onset neonatal sepsis. J Pediatr (Rio J). 2004;80:407-10. 
IL-6 is an early marker of neonatal sepsis. Several studies have shown sensitivity in the range of 75 to $90 \%$ in the first 24 hours of neonatal infection, and an abrupt decrease 48 hours after the beginning of clinical manifestations. ${ }^{6-9}$ Recent studies reported high IL-6 levels in umbilical cord blood in newborns with early-onset sepsis whose mothers had chorioamnionitis. ${ }^{10,11}$ However, even though some newborn infants presented neonatal infection, they had low plasma IL- 6 levels. ${ }^{12}$

The aim of this study is to assess different perinatal findings and sample collection timing in newborns with early-onset sepsis comparing those with low IL-6 levels to the ones with high levels.

\section{Patients and methods}

The study protocol was approved by the Ethics Committee at the Hospital de Clínicas de Porto Alegre and informed consent was obtained from patients' parents or guardians. The samples were collected before starting antibiotic therapy, simultaneously with blood for routine exams.

\section{Study population}

We prospectively studied consecutively born neonates with gestational age equal to or higher than 34 weeks delivered at the obstetric center at the Hospital de Clínicas de Porto Alegre and admitted to the neonatal intensive care unit with diagnosis of early-onset sepsis that was defined by clinical manifestation and/or positive blood culture within the first 96 hours of life. All newborns had one additional blood sample collected for IL- 6 measurement at the moment of clinical suspicion of infection.

The exclusion criteria were Apgar score lower than 8 at 5 minutes of life, clinical or laboratory evidence of congenital infection, congenital malformation, maternal syphilis, toxoplasmosis, rubella, cytomegalovirus, herpes virus 1 and 2 during pregnancy, HIV-positive mothers, and pre and post natal use of corticosteroid.

The criteria for diagnosis of sepsis were as follows: presence of positive blood culture, or negative blood culture with the newborn presenting clinical signs of infection. The latter was determined by the presence of three or more of the following:2,6 a) maternal risk factors such as fever, premature rupture of membranes for longer than 18 hours, and urinary tract infection; b) clinical findings such as apnea, difficult breathing, cyanosis; tachycardia or bradycardia, perfusion deficit or shock; irritability, lethargy; hypotonia, seizures; abdominal distention, vomits, food intolerance, gastric residue, hepatomegaly; unexplained jaundice; thermal instability; petechiae or purpura; and a general appearance of "not being well."

\section{Classification of newborns}

Newborn infants were classified in two groups according to their plasma IL-6 levels: higher, and equal to or lower than IL- 6 median value for the whole septic group.
High level group: septic newborn infants with IL-6 levels higher than the median for the whole septic group.

Low level group: septic newborn infants with IL-6 levels equal to or lower than the whole septic group median.

\section{Determination of IL-6 in plasma}

The blood samples $(100 \mu \mathrm{l})$ were collected in tubes with EDTA and centrifuged immediately; the plasma was frozen at $-70^{\circ} \mathrm{C}$. No venous punctures were performed exclusively for the study.

The measurement of IL- 6 was performed using an enzyme immunoassay (Quantikine Human IL-6 R \& $D$ Systems, Inc. MN, USA). The detection limit was $0.7 \mathrm{pg} / \mathrm{ml}$, with intra and interassay coefficients of variation below $5 \%$. Readings were carried out in an automated optical Spectramax reader at $570 \mathrm{~nm}$.

\section{Statistical analysis}

The results are expressed as means \pm standard deviation (SD) or medians and interquartile range (p25-p75). Differences between means were analyzed by Student's $t$ test. Chi-square or Fisher's exact test were employed for fourfold tables.

Since logarithmic functions were used for the comparison of IL-6 levels in the two groups, we were able to employ Student's $t$ test for independent samples. Mann-Whitney test was used for differences in sample timing. Pearson's correlation coefficient was calculated for IL- 6 and collection timing. Significance was established at $p<0.05$.

Sample size was calculated to be a total of 60 patients, considering a significance level of $0.05,90 \%$ power, and a difference in IL-6 levels between the groups of $20 \%$.

\section{Results}

Eighty-five newborns with diagnosis of neonatal earlyonset sepsis were enrolled in the study. The whole group median IL-6 was $89 \mathrm{pg} / \mathrm{ml}$. High level group (IL-6 > 89 $\mathrm{pg} / \mathrm{ml}$ ) was formed by 42 newborns, and low level group (IL-6 $\leq 89 \mathrm{pg} / \mathrm{ml}$ ) by 43 newborns.

Maternal risk factors for infection were present in 59 (69\%) newborn infants: clinical chorioamnionitis in 15 , clinical chorioamnionitis associated with urinary tract infection (UTI) in seven, premature rupture of membranes $>18$ hours (PROM) in 11, PROM associated with UTI in seven, UTI in 14 , and fever in five.

The two groups had similar birth weights, gestational ages, proportion of cesarean-section deliveries, Apgar scores, number of neonates with maternal risk factors for infection, and number of positive blood cultures. Eighteen patients had positive blood cultures, nine in each group with the following distribution: Group B Streptococcus in seven (39\%), Staphyloccus aureus in eight (44\%), coagulasenegative Staphyloccus in one, Enterococcus faecalis in one, and gram-negative oxidase-negative bacillum in one. There were no differences between the groups regarding 
intrapartum maternal antibiotic therapy (ampicillin): 12 mothers received antibiotics in the high level group and 10 mothers in the low level group (Table 1).

The median IL-6 in high level group was $287 \mathrm{pg} / \mathrm{ml}$ and in low level group was $46 \mathrm{pg} / \mathrm{ml}$, and the median sample collection timing was 17.5 hours of life for the high level group and 36 for the low level group. Those differences were statistically significant (Table1). There was a significant negative correlation coefficient between IL-6 levels and sample collection timing $(r=-0.4, p<0.001)$.

When just the newborns with positive blood cultures were considered, the difference in median sample timing was also statistically significant: 20 and 77 hours of life for high and low level groups respectively ( $p<0.001)$.

Median IL-6 levels were similar in septic newborns with and without positive blood cultures: 108 and $121 \mathrm{pg} / \mathrm{ml}$, respectively.

\section{Discussion}

IL-6 is an important neonatal inflammatory mediator. There are several studies demonstrating an elevation of plasma IL-6 levels in septic newborn infants. $6,13,14$ Balance between pro and anti-inflammatory cytokines is determinant for their blood levels. Low IL-10 plasma level in infected newborn infants contribute to an increase of IL-6.4,15,16

In animal studies, IL-6 maximum levels are reached three and half hours after induced endotoxemia. Six hours later, the levels are already very low. ${ }^{17}$ Sample collection timing is an important factor that must be taken into account in order to detect IL-6 peak level in sepsis.

Infants with early-onset sepsis very often present maternal risk factors for infection; they are generally contaminated in the uterus or during labor and delivery. ${ }^{18}$
Elevation of inflammatory mediators will probably occur in the early course of disease. 10,19

We studied neonates with gestational age equal to or higher than 34 weeks that presented early-onset sepsis defined by clinical manifestation and/or positive blood culture in the first 96 hours of life. Septic neonates were divided into two groups using the whole group median IL-6 level as the cutoff point. Newborn infants with low and high IL-6 levels were similar in all studied characteristics, except for sample collection timing.

Since our objective was to compare high and low IL-6 early-onset septic newborns in relation to different perinatal findings and sample collection timing, and it is already well known that IL-6 levels are high in infected newborns, it was not judged necessary to include a control group in the study. ${ }^{5-9}$

Neither very premature infants or those whose mothers had been exposed to prenatal corticosteroids were included in the study. Ex-vivo sepsis study has shown a decreased IL6 presence in monocytes of those infants in comparison to term and near-term newborns, and adults. ${ }^{20}$

Recently, we showed that term newborn infants with hypoxic-ischemic encephalopathy have high plasma and CSF IL- 6 levels, demonstrating that local production of IL- 6 in the brain of newborns is very significant. ${ }^{21}$ Therefore, asphyxiated septic infants were not included in this study.

Even though blood samples were collected as soon as clinical findings of sepsis were detected, the lowest IL-6 levels were found in neonates whose collection was performed with more than 24 life hours. Since most of the patients included in the study presented clinical manifestation early on, it is assumed that sepsis origin was perinatal in most of them. ${ }^{22}$ Thus clinical manifestations may appear several hours after bacterial invasion.

Table 1 - Clinical and laboratory data of the studied newborns

\begin{tabular}{lcc}
\hline & High level group & Low level group \\
\hline Number of newborns & 42 & 43 \\
Birth weight (grams) & $3,002 \pm 745$ & $3,054 \pm 710$ \\
Gestational age (weeks) & $38.3 \pm 1.9$ & $38.3 \pm 2.2$ \\
Cesarean-section & $14(33 \%)$ & $15(35 \%)$ \\
Apgar 5 min & $9(8-10)$ & $9(8-10)$ \\
Intrapartum maternal antibiotic & $12(28.5 \%)$ & $10(23.3 \%)$ \\
Maternal risk factors for infection & $31(73.8 \%)$ & $28(65 \%)$ \\
Sample timing (hours of life) * & $17.5(12-24)$ & $36(21-57)$ \\
& {$[4-77]$} & {$[3-96]$} \\
IL-6 levels $(\mathrm{pg} / \mathrm{ml}) *$ & $287(149-1,455)$ & $46(33.6-69.7)$
\end{tabular}

Data expressed as mean \pm standard deviation or median with interquartile range (p25-p75) and [range: min-max]

${ }^{*}$ Statistically significant difference, $p<0.001$. 
At the moment, clinical applicability of cytokines is not practical because enzyme immunoassay is expensive and takes several hours to be performed. A readily available, automatic assay is necessary for clinical purposes, and will be accessible in the future. ${ }^{9}$

We demonstrated that IL- 6 is a very early and sensitive marker for neonatal sepsis, ${ }^{5}$ and now we suggest that the presence of a maternal risk factor or any subtle neonatal clinical sign is enough to indicate IL-6 sample collection for very early sepsis diagnosis. Therefore, our data suggest that high IL-6 levels in newborn infants with early-onset sepsis is related to early sample collection timing, within the first 24 life hours.

\section{Acknowledgments}

The authors thank Prof. Isaura Riedl for the English revision.

\section{References}

1. Kishimoto T. The biology of interleukin-6. Blood. 1989;74:1-10.

2. Gerdes JS. Clinicopathologic approach to the diagnosis of neonatal sepsis. Clin Perinatol. 1991;18:361-81.

3. Hirano T. The biology of interleukin-6. Chem Immunol. 1992;51: 153-80.

4. Cohen MC, Cohen S. Cytokine function: a study in biologic diversity. Am J Clin Pathol. 1996;105:589-98.

5. Buck C, Bundschu J, Gallati H, Bartman P, Pohlandt F. Interleukin6: a sensitive parameter for the early diagnosis of neonatal bacterial infection. Pediatrics. 1994;93:54-8.

6. Silveira RC, Procianoy RS. Evaluation of interleukin-6, tumor necrosis factor- $\alpha$ and interleukin- $1 \beta$ for early diagnosis of neonatal sepsis. Acta Paediatr. 1999;88:647-50.

7. Panero A, Pacifico L, Rossi N, Mancuso G, Stegagno M, Chiesa C. Interleukin-6 in neonates with early and late onset infection. Pediatr Infect Dis J. 1997;16:370-7.

8. de Bont ES, Martens A, van Raan J, Samson G, Fetter WP, Okken $A$, et al. Diagnostic value of plasma levels of tumor necrosis factor $\alpha$ (TNF- $\alpha$ ) and interleukin-6 (IL-6) in newborn with sepsis. Acta Paediatr. 1994;83:696-9.

9. Mehr S, Doyle LW. Cytokines as marker of bacterial sepsis in newborn infants: a review. Pediatr Infect Dis J. 2000;19:879-87.

10. Yoon BH, Romero R, Park JS, Kim M, Oh SY, Kim CJ, et al. The relationship among inflammatory lesions of the umbilical cord (funisitis), umbilical cord plasma interleukin-6 concentration, amniotic fluid infection, and neonatal sepsis. Am J Obstet Gynecol. 2000;183:1124-9.
11. Naccasha $N$, Hinson $R$, Montag $A$, Ismail M, Bentz $L$, Mittendorf $R$. Association between funisitis and elevated interleukin- 6 in cord blood. Obstet Gynecol. 2001;97:220-4.

12. Reyes CS, García-Muñoz, Reyes D, Gonzales G, Dominguez C, Domenech E. Role of cytokines (interleukin-1B, 6, 8, tumor necrosis factor- $\alpha$, and soluble receptor of interleukin-2) and Creactive protein in the diagnosis of neonatal sepsis. Acta Paediatr. 2003;92:221-7.

13. Chiesa C, Pellegrini G, Panero A, Osborn JF, Signore F, Assumma $M$, et al. C-Reactive protein, interleukin- 6 , and procalcitonin in the immediate postnatal period: influence of illness severity, risk status, antenatal and perinatal complications, and infection. Clin Chem. 2003;49:60-8.

14. Dollner $H$, Vatten $L$, Austgulen R. Early diagnostic markers for neonatal sepsis: Comparing C-reactive protein, interleukin- 6 soluble tumor necrosis factor receptors and soluble adhesion molecules. J Clin Epidemiol. 2001;54:1251-7.

15. Messer J, Eyer D, Donato L, Gallati H, Matis J, Simeoni U. Evaluation of IL- 6 and soluble of tumor necrosis factor for early diagnosis of neonatal infection. J Pediatr. 1996;129:574-80.

16. Damman O, Leviton A. Brain damage in preterm newborns: Biological response modification as a strategy to reduce disabilities. J Pediatr. 2000;136:433-8.

17. Anderson MR, Blumer JL. Advances in the therapy for sepsis in children. Pediatr Clin North Am. 1997;44:179-86.

18. Stoll BJ, Hansen N, Fanaroff AA, Wright LL, Carlo WA, Ehrenkranz $R A$, et al. Changes in pathogens causing early-onset sepsis in very-low-birth-weight infants. N Engl J Med. 2002;347:240-7.

19. Shalak LF, Laptook AR, Jafri HS, Ramilo O, Perlman JM. Clinical chorioamnionitis, elevated cytokines, and brain injury in term infants. Pediatrics. 2002;110:637-80.

20. Schultz C, Rott C, Temming P, Schlenke P, Möller JC, Bucsky P. Enhanced interleukin- 6 and interleukin- 8 synthesis in term and preterm infants. Pediatr Res. 2002; 51:317-22.

21. Silveira RC, Procianoy RS. Interleukin- 6 and tumor necrosis factor- $\alpha$ levels in plasma and cerebrospinal fluid of term newborn infants with hypoxic-ischemic encephalopathy. J Pediatr. 2003; 143:625-9.

22. Klein JO. Bacterial sepsis and meningitis. In: Remington JS, Klein JO, editors. Infectious diseases of the fetus and newborn infants. 5th ed. Philadelphia: W. B. Saunders; 2001. p. 943-998.

Corresponding author:

Renato S. Procianoy

Rua Tobias da Silva, 99/302

CEP 90570-020 - Porto Alegre, RS

Brazil

Phone: +55 (51) 3222.7889

Fax: +55 (51) 3331.2738

E-mail: renatosp@terra.com.br 